\title{
Digestible lysine levels in diets supplemented with ractopamine
}

\section{Evelar de Oliveira Souza1 ${ }^{1}$, Douglas Haese ${ }^{2}$, João Luís Kill², Ismail Ramalho Haddade ${ }^{3}$, Elcio das Graça Lacerda ${ }^{1}$, Alysson Saraiva ${ }^{2}$, Francisco Carlos de Oliveira Silva ${ }^{4}$, Rodrigo Pereira Sobreiro ${ }^{1}$}

\footnotetext{
${ }^{1}$ Mestrando em Ciência Animal, UVV.

2 Medicina Veterinária, UVV.

3 IFES-CST.

${ }^{4}$ EPAMIG.
}

ABSTRACT - In order evaluate digestible lysine levels in diets supplemented with $20 \mathrm{ppm}$ of ractopamine on the performance and carcass traits, 64 barrows with high genetic potential at finishing phase were allotted in a completely randomized block design with four digestible lysine levels $(0.80,0.90,1.00$, and $1.10 \%)$, eight replicates and two pigs per experimental unit. Initial body weight and pigs' kinship were used as criteria in the blocks formation. Diets were mainly composed of corn and soybean meal supplemented with minerals, vitamins and amino acids to meet pigs' nutritional requirements at the finishing phase, except for digestible lysine. No effect of digestible lysine levels was observed in animal performance. The digestible lysine intake increased linearly by increasing the levels of digestible lysine in the diets. Carcass traits were not influenced by the dietary levels of digestible lysine. The level of $0.80 \%$ of digestible lysine in diets supplemented with $20 \mathrm{ppm}$ ractopamine meets the nutritional requirements of castrated male pigs during the finishing phase.

Key Words: additive, amino acid, carcass, diet, meat

\section{Introduction}

The consumer's demand for high quality products has increased the interest in producing animals with high lean meat deposition and low fat. Carcass meat deposition is therefore an important variable in pig production and is related to the genetic potential of animals. The expression of genetic potential depends on environmental and dietary factors, among others.

Dietary lysine has been considered the nutrient that most affects protein deposition. This is due to its constancy in the body protein and preferential metabolic destination for lean tissue deposition (Knabe, 1996). The factors that affect protein accretion rate can affect lysine requirement in pigs selected for high lean deposition in the carcass (Abreu, 2005). According to Stahly et al. (1994) and Friesen et al. (1995), pigs with high potential for lean deposition require higher levels of dietary lysine.

After achieving the plateau for body protein gain pigs present reduced feed efficiency and increased carcass fat deposition. However, the development of more efficient and rapid growth strains and the adoption of new technologies such as carcass modifiers ( $\beta$-adrenergic agonists) has led to an increase of slaughter weight with no loss of lean tissue deposition and feed efficiency (Sanchez et al., 2010).
The $\beta$-adrenergic agonist ractopamine is a feed additive similar in structure to catecholamines, epinephrine and norepinephrine. It acts on beta-adrenergic receptors decreasing fat deposition, promoting lipolysis and increasing body protein synthesis (Spurlock et al., 1993). According to Kiefer \& Sanchez (2009) and Sanchez et al. (2010), supplementation with $20 \mathrm{ppm}$ of ractopamine improves performance and carcass traits of pigs.

Studies on digestible lysine requirements for barrows with high genetic potential during the finishing phase, fed ractopamine-supplemented diets based on the results of performance and carcass traits are, therefore, necessary.

\section{Material and Methods}

The experiment was carried out in the Setor de Suinocultura in Instituto Federal do Espírito Santo (IFES), located in Santa Teresa, ES, between October and December 2009.

A total of 64 barrows with high genetic potential and average initial weight of $90.19 \pm 0.46 \mathrm{~kg}$ were used. Pigs were allotted in a completely randomized block design with four levels of lysine $(0.8,0.9,1.0$, and $1.1 \%)$, eight replicates and two pigs per experimental unit. Initial body weight and pigs' kinship were used as criteria in the blocks formation. 
Pigs were housed in pens equipped with semi-automatic feeders and nipple waterers, in a concrete floor facility with asbestos tiling. Temperature and humidity within the facility were registered by maximum and minimum thermometer and dry and wet bulb thermometers.

The experimental diets (Table 1) were mainly composed of corn and soybean meals supplemented with minerals, vitamins, and amino acids to meet the nutritional requirements for finishing-phase pigs, except for lysine, according to Rostagno et al. (2005). All diets were supplemented with $20 \mathrm{ppm}$ of ractopamine.

Feed intake of pigs from each pen was evaluated and pigs were individually weighed at the beginning and at the end of the experimental period (28 days) to determine daily weight gain, feed conversion, feed intake and daily digestible lysine intake.

Carcass evaluation in vivo was carried out by ultrasound measurements (105 Piglog $\left.{ }^{\circledR}\right)$ of carcass traits at the beginning of the experiment and on the $28^{\text {th }}$ day. Ultrasound measurements' readings were taken from the left side of animals. Barrows were ultrasonically measured for backfat thickness at point P1 (ETP1) measured at $6.5 \mathrm{~cm}$ from dorsolumbar line (between the penultimate and last vertebra) and at P2 (ETP2) - measured at $6.5 \mathrm{~cm}$ from dorsolumbar line and at $6.5 \mathrm{~cm}$ from the last rib in the cranial direction.

At the end of the experiment, one pig from each experimental unit was slaughtered after $24 \mathrm{~h}$ diet fasting and $12 \mathrm{~h}$ water fasting. Animals were slaughtered by stunning followed by exsanguination. Carcasses were then shaved with flamethrowers and eviscerated. Carcass weight was measured including feet and head with an electronic scale and sawn lengthwise along the spine. Half-carcasses were weighed separately. Carcass yield was obtained by the ratio between animal weight in fasting and hot carcass weight.

The left half carcasses were cut with a caliper to expose the longissimus dorsi muscle and backfat and measure muscle depth (LDD). Loin-eye area (LEA) was traced on vegetal paper sheet placed over the loin and outlined with a fine tip marker pen. The muscle tracing was placed on graph paper and the area was calculated according to Bridi \& Silva (2007). Carcass length was also measured according to the Brazilian Method of Carcass Classification (CCMB); the length between cranial edge of the symphysis pubis and cranial-ventral edge of the atlas (ABCS, 1973) by the American Method of Carcass Classification (CCMA) and the length from cranial edge of the symphysis pubis to the cranial-ventral edge of the first rib (Boggs \& Merkel, 1979).

Table 1 - Centesimal composition of experimental diets for high performance barrows

\begin{tabular}{|c|c|c|c|c|}
\hline \multirow[t]{2}{*}{ Ingredient } & \multicolumn{4}{|c|}{ Digestible lysine level (\%) } \\
\hline & 0.80 & 0.90 & 1.00 & 1.10 \\
\hline Corn & 77.181 & 74.348 & 70.316 & 66.284 \\
\hline Soybean meal & 19.658 & 22.980 & 26.875 & 30.769 \\
\hline Soybean oil & 0.000 & 0.085 & 0.194 & 0.304 \\
\hline Limestone & 0.329 & 0.326 & 0.322 & 0.318 \\
\hline Dicalcium phosphate & 1.045 & 1.022 & 0.996 & 0.969 \\
\hline Salt & 0.403 & 0.403 & 0.403 & 0.403 \\
\hline DL-methionine $99 \%$ & 0.019 & 0.054 & 0.084 & 0.114 \\
\hline L-lysine $\mathrm{HCl}$ 78\% & 0.199 & 0.227 & 0.239 & 0.251 \\
\hline L-threonine $98 \%$ & 0.030 & 0.055 & 0.072 & 0.090 \\
\hline Vitamin and mineral premix ${ }^{1}$ & 0.400 & 0.400 & 0.400 & 0.400 \\
\hline Ractopamine $^{2}$ & 0.100 & 0.100 & 0.100 & 0.100 \\
\hline \multicolumn{5}{|l|}{ Calculated nutritional composition } \\
\hline Metabolizable energy (kcal/kg) & 3230 & 3230 & 3230 & 3230 \\
\hline Crude protein (\%) & 15.55 & 16.84 & 18.31 & 19.78 \\
\hline Digestible methionine + cystine (\%) & 0.496 & 0.558 & 0.620 & 0.682 \\
\hline Digestible lysine (\%) & 0.800 & 0.900 & 1.000 & 1.100 \\
\hline Digestible threonine (\%) & 0.536 & 0.603 & 0.670 & 0.737 \\
\hline Digestible tryptophan (\%) & 0.155 & 0.171 & 0.190 & 0.209 \\
\hline Digestible arginine (\%) & 0.907 & 1.001 & 1.110 & 1.220 \\
\hline Digestible isoleucine (\%) & 0.564 & 0.618 & 0.681 & 0.744 \\
\hline Digestible valinel (\%) & 0.650 & 0.701 & 0.762 & 0.823 \\
\hline Calcium (\%) & 0.453 & 0.453 & 0.453 & 0.453 \\
\hline Available phosphorus (\%) & 0.245 & 0.245 & 0.245 & 0.245 \\
\hline Sodium (\%) & 0.160 & 0.160 & 0.160 & 0.160 \\
\hline
\end{tabular}


Left half carcass was also assessed for: backfat thickness measured at $6.5 \mathrm{~cm}$ from dorsolumbar line (between the penultimate and last lumbar vertebra) in a caudal direction (P1); backfat thickness measured after last rib, $6.5 \mathrm{~cm}$ in the dorsolumbar line (P2); backfat thickness after last rib in the dorsolumbar line (UC); backfat thickness between penultimate and last lumbar vertebra, in the dorsolumbar line (UL); and higher backfat thickness at last $2^{\text {nd }}-3^{\text {rd }}$ thoracic vertebra, in the dorsolumbar line ( $\left.\mathrm{SH}\right)$.

The right carcass was chilled $\left(4-8^{\circ} \mathrm{C}\right)$ for 24 hours for determination of ham yield (expressed as the total halfcarcass weight in relation to chilled half-carcass weight); loin yield (expressed as total loin weight in relation to chilled half-carcass weight); sirloin yield (expressed as the total sirloin weight in relation to chilled half-carcass weight) and meat yield according to the formula described by Smith \& Bridi (2009), where meat yield (\%) = 60 - (back fat thickness $(\mathrm{mm}) \times 0.58)+[$ muscle depth $(\mathrm{mm}) \times 0.10$ ] .

Data were statistically analyzed using the System for Statistics and Genetics (SAEG), developed at the Universidade Federal de Viçosa - UFV (1999). Regression analysis was done using linear and quadratic effects to determine digestible lysine requirements.

\section{Results and Discussion}

Average temperatures observed in the maximum/minimum thermometer and relative humidity were $30.7 \pm 3.2^{\circ} \mathrm{C}$, $23.9 \pm 1.5^{\circ} \mathrm{C}$, and $71.4 \pm 11.9 \%$, respectively. Heat stress may have occurred, considering the comfort zone for finishing pigs (Ferreira, 2005). However, the heat stress must not have been enough to impair pigs' performance since the average daily gain was similar to that reported by Rostagno et al. (2005).

No effect $(\mathrm{P}>0.05)$ was observed for digestible lysine levels on pigs weight gain (Table 2). Similarly, Marinho et al. (2007a) found no effect of digestible lysine levels (0.67 and $0.87 \%$ ) in diets with or without ractopamine (5.0 ppm) on pigs' performance. Arouca et al. (2007) assessed the levels of digestible lysine (0.50- to $0.90 \%$ ) for 95 - to $122-\mathrm{kg}$ pigs and found a lysine requirement of $0.71 \%$. Kiefer \& Sanchez (2009) verified that pigs' weight gain linearly increased as dietary lysine increased in all levels of ractopamine, including the diet with no ractopamine.

Feed intake was not affected $(\mathrm{P}>0.05)$ by the digestible lysine levels, which is consistent with the results obtained by Friesen et al. (1995), Cline et al. (2000), Arouca et al. (2005), Abreu et al. (2007), Arouca et al. (2007) and Marino et al. (2007b). Other authors (Gonçalves et al., 1999; Oliveira et al. 2003) have however observed reductions in feed intake with increasing levels of dietary lysine. This variation in the results concerning the influence of lysine levels on the voluntary intake by pigs may be associated to the energy level and imbalance of amino acids in the diet, among other factors.

According to D'Mello (1993) the consumption of unbalanced diets affects amino acid concentration in the plasma and tissues, resulting in reduced feed intake and animal growth. In the present study diets were isocaloric and the imbalance of amino acids was prevented by the addition of industrial amino acids, keeping the ratio recommended by Rostagno et al. (2005) in the ideal protein concept, following the increase in the levels of lysine.

No effect $(\mathrm{P}>0.05)$ of the digestible lysine levels was observed on feed conversion. Similar results were obtained by Moreira et al. (2002), Marino et al. (2007b) and Almeida (2008). However, the influence of different levels of dietary lysine on feed conversion of pigs was reported by several authors (Cline et al., 2000; Arouca et al., 2005; Abreu et al., 2007; Arouca et al., 2007).

The average lysine intake of pigs showed linear increase $(\mathrm{P}<0.01)$ as the dietary lysine levels increased. The linear effect observed for lysine intake was a response to the different levels of lysine in diets, since there was no effect ( $\mathrm{P}>0.05$ ) of lysine level on feed intake. Abreu et al. (2007) and Arouca et al. (2005) also observed an increase in lysine intake during the finishing phase.

The was no effect $(\mathrm{P}>0.05)$ of lysine levels on the in vivo backfat thickness (ETP1 and ETP2) of pigs (Table 3). These results are consistent with the studies of Arouca et al. (2005)

Table 2 - Body weight and performance of finishing pigs fed diets with different levels of digestible lysine added 20 ppm ractopamine

\begin{tabular}{lccccc}
\hline Variable & \multicolumn{2}{c}{ Digestible lysine leval (\%) } & \multicolumn{2}{c}{ CV (\%) } \\
\cline { 2 - 5 } & 0.80 & 0.90 & 1.00 & 1.10 & \\
\hline Initial body weight (kg) & 90.2 & 90.2 & 90.3 & 90.4 & NS \\
Weight at 28 days (kg) & 121.2 & 122.8 & 121.7 & 121.9 & 4.0 \\
Daily weight gain (g) & 1096 & 1149 & 1120 & 1121 & NS \\
Daily feed intake (g) & 2804 & 2951 & 2704 & 2752 & NS \\
Feed conversion (kg/kg) & 2.6 & 2.6 & 2.4 & 2.5 & NS \\
Digestible lysine intake* (g/day) & 22.4 & 26.5 & 27.0 & 30.3 & NS \\
\hline
\end{tabular}

*Linear effect; NS = not significant; CV = coefficient of variation. 
and Arouca et al. (2007), who assessed lysine levels for finishing pigs and found no effect on these parameters. Marinho et al. (2007b) evaluated two lysine levels (0.67 and $0.87 \%$ ) in finishing pigs and observed reduction in EPT1 and ETP2 in the finishing phase with $0.87 \%$ digestible lysine.

Although no significant effect was observed, there was a reduction in the values of backfat thickness for P1 (EPT1) and P2 (EPT2) at the end of the experiment (with average values of 0.39 and $0.17 \mathrm{~mm}$, respectively) compared with the beginning of the experiment. It is possible that the effect of ractopamine reduced backfat thickness, since no difference $(\mathrm{P}>0.05)$ was observed among the levels of digestible lysine. According to Mersmann et al. (1998), dietary inclusion of this additive in diets for pigs stimulates triglycerides degradation in adipocytes and inhibits fat synthesis.

There was no effect $(\mathrm{P}>0.05)$ of digestible lysine levels on carcass length according to the Brazilian and American methods (Table 4). Similar results were found by Oliveira et al. (2002), Kill et al. (2002a) and Arouca et al. (2005), with

Table 3 - In vivo carcass traits in finishing barrows fed diets containing different levels of digestible lysine added 20 ppm ractopamine

\begin{tabular}{|c|c|c|c|c|c|c|}
\hline \multirow[t]{2}{*}{ Item } & \multicolumn{4}{|c|}{ Digestible lysine level (\%) } & \multirow[t]{2}{*}{ CV (\%) } & \multirow[t]{2}{*}{$P$} \\
\hline & 0.80 & 0.90 & 1.00 & 1.10 & & \\
\hline \multicolumn{7}{|l|}{ ETP1 (mm) } \\
\hline Initial & 12.21 & 12.43 & 12.36 & 12.07 & 8.27 & NS \\
\hline $\begin{array}{l}\text { At } 28 \text { days } \\
\text { ETP2 }(\mathrm{mm})\end{array}$ & 10.86 & 11.57 & 9.93 & 11.36 & 11.69 & NS \\
\hline Initial & 11.43 & 11.64 & 10.79 & 11.07 & 10.59 & NS \\
\hline At 28 days & 10.50 & 10.71 & 9.21 & 10.29 & 13.94 & NS \\
\hline
\end{tabular}

no effect of dietary lysine levels on these variables. The values of backfat thickness measured at different points in the carcass (P1, P2, UC, UL and HS) showed no difference among digestible lysine levels. Kill et al. (2002b) and Oliveira et al. (2002), in a study with finishing pigs, also observed no significant differences in backfat thickness at the last rib and between the penultimate and last lumbar vertebra.

Carcass and cuts yield (ham, shoulder, rib and sirloin), lean meat yield, longissimus dorsi depth (LDD) and loin-eye area (LEA) were not $(\mathrm{P}>0.05)$ affected by the digestible lysine levels (Table 5). Similar results were found by several authors (Oliveira et al., 2003; Arouca et al., 2005; Arouca et al., 2007; Pereira et al., 2008), who assessed different digestible lysine levels in finishing pigs and found no effect on carcass traits with no addition of ractopamine in the diet.

Moreover, Mitchell et al. (1991), Xiao et al. (1999), Marino et al. (2007a), Kiefer \& Sanchez (2009) reported that lysine requirements for higher lean meat percentages and lower fat thickness in pigs fed diets containing ractopamine is higher than in diets without ractopamine. This may have been caused by nutrient partitioning through the action of ractopamine, resulting in possible changes in protein and lipid metabolism, with an increased protein deposition rate at the expense of lipid deposition.

According to Kiefer \& Sanchez (2009), lean meat percentage in pigs fed diets containing ractopamine can be related to dietary lysine concentrations and linearly improves the level of digestible lysine to $1.00 \%$. This value differs from the results obtained in this study since there was no effect $(\mathrm{P}>0.05)$ of lysine levels on lean meat yield.

Although lean meat yield (average 61.5\%) was not significant, in absolute values this parameter showed improvements when compared with the results reported by Oliveira et al. (2003) and Arouca et al. (2007), who

Table 4 - Carcass traits in finishing barrows fed diets containing different levels of digestible lysine added 20 ppm ractopamine

\begin{tabular}{|c|c|c|c|c|c|c|}
\hline \multirow[t]{2}{*}{ Item } & \multicolumn{4}{|c|}{ Digestible lisine level (\%) } & \multirow[t]{2}{*}{ CV (\%) } & \multirow[t]{2}{*}{$P$} \\
\hline & 0.80 & 0.90 & 1.00 & 1.10 & & \\
\hline \multicolumn{7}{|c|}{ Carcass length $(\mathrm{cm})$} \\
\hline ССМB & 101.4 & 100.5 & 99.6 & 101.5 & 3.39 & 0.28 \\
\hline CCMA & 85.07 & 84.81 & 84.00 & 85.00 & 3.74 & NS \\
\hline \multicolumn{7}{|c|}{ Backfat thickness (mm) } \\
\hline P 1 & 10.3 & 11.9 & 8.8 & 10.1 & 19.58 & 0.31 \\
\hline P 2 & 9.4 & 9.7 & 7.7 & 9.3 & 19.97 & 0.33 \\
\hline UC & 16.6 & 16.2 & 14.9 & 14.4 & 17.05 & 0.20 \\
\hline UL & 14.1 & 14.3 & 11.8 & 12.6 & 23.96 & 0.09 \\
\hline $\mathrm{SH}$ & 35.7 & 35.3 & 34.8 & 35.7 & 11.12 & NS \\
\hline
\end{tabular}

CCMB = carcass length measured according to the Brazilian Method of Carcass Classification; CCMA = carcass length measured according to the American Method of Carcass Classification; P1 = backfat thickness measured at $6.5 \mathrm{~cm}$ from the dorsolumbar line and between the last and penultimate lumbar vertebra; P2 = backfat thickness measured immediately after the last rib, at $6.5 \mathrm{~cm}$ from the dorsolumbar line; UC = backfat thickness immediately after the last rib in the dorsolumbar line; UL = back fat thickness between the last and the penultimate lumbar vertebra in the dorsolumbar line; $\mathrm{SH}=$ higher backfat thickness at last $2^{\text {nd }}-3^{\text {rd }}$ thoracic vertebra, in the dorsolumbar line; NS = not significant. 
Table 5 - Carcass, cuts, and lean meat yields, longissimus dorsi depth (LDD) and loin-eye area of finishing barrows fed diets containing different levels of digestible lysine added 20 ppm ractopamine

\begin{tabular}{|c|c|c|c|c|c|c|}
\hline \multirow[t]{2}{*}{ Item } & \multicolumn{4}{|c|}{ Digestible lysine level (\%) } & \multirow[t]{2}{*}{ CV (\%) } & \multirow[t]{2}{*}{$P$} \\
\hline & 0.80 & 0.90 & 1.00 & 1.10 & & \\
\hline \multicolumn{7}{|l|}{ Yield (\%) } \\
\hline Ham & 28.81 & 28.39 & 28.61 & 27.97 & 4.63 & 0.18 \\
\hline Pork shoulder & 27.32 & 27.32 & 27.19 & 27.55 & 5.41 & NS \\
\hline Carrè & 14.15 & 15.03 & 14.56 & 14.48 & 6.60 & NS \\
\hline LDD (mm) & 68.39 & 64.61 & 70.41 & 65.61 & 7.03 & NS \\
\hline Loin-eye area $\left(\mathrm{cm}^{2}\right)$ & 50.86 & 49.30 & 54.50 & 50.28 & 9.03 & NS \\
\hline
\end{tabular}

NS = not significant; CV = coefficient of variation.

found 55.83 and $53.5 \%$, respectively, in pigs fed different lysine levels without ractopamine. According to Spurlock et al. (1993), when administered in diets for pigs, $\beta$ adrenergic agonist ractopamine increases the amount of lean carcass deposition by increasing muscle and reducing fat deposition, improving the fat/meat ratio in carcass. This occurs due to increased muscle protein synthesis or decreased degradation. There is evidence that animals treated with ractopamine show decrease in protease activity due to the increased concentration of proteolytic inhibitors (Spurlock et al., 1993).

Kiefer \& Sanchez (2009), in an assessment based on the meta-analysis of the ractopamine levels for finishing pigs, reported that the rib-eye area in animals fed diets containing 0 or 5 ppm did not affect lysine levels. However, the rib-eye area in pigs fed diets containing 10 and $20 \mathrm{ppm}$ of ractopamine varies quadratically and increases to the estimated level of $0.81 \%$ digestible lysine. Therefore, despite the absence of effect ( $\mathrm{P}>0.05)$ of lysine levels on the rib-eye area, the average value of $51.23 \mathrm{~cm}^{2}$ found in this study was higher than those described by Oliveira et al. (2003) and Abreu et al. (2007): $39.99,41.09$ and $42.8 \mathrm{~cm}^{2}$, respectively, in diets with different levels of lysine supplementation without ractopamine.

\section{Conclusions}

Considering the performance parameters and carcass traits, the $0.80 \%$ lysine level in diets with 20 ppm of ractopamine meets the requirements of barrows in the finishing phase.

\section{Acknowledgements}

The authors would like to thank the Instituto Federal do Espírito Santo, Campus Santa Teresa (IFES-CST), for providing space and facilities for the conduction of the research, the NUTRIAVE ALIMENTOS industry for the financial support in this study and Ourofino, for donating RACTOSUIN.

\section{References}

ABREU, M.L.T.; DONZELE, J.L.; OLIVEIRA, R.F.M. et al. Níveis de lisina digestível em rações, utilizado-se o conceito de proteína ideal, para suínos machos castrados de alto potencial genético para deposição de carne magra na carcaça dos 60 aos $95 \mathrm{~kg}$. Revista Brasileira de Zootecnia, v.36, n.1, p.54-61, 2007.

AROUCA, C.L.C.; FONTES, D.O.; VELOSO, J.A.F. et al. Exigências de lisina, com base no conceito de proteína ideal, para suínos machos castrados dos 96 aos 120 kg, selecionados para eficiência de crescimento. Arquivo Brasileiro de Medicina Veterinária e Zootecnia, v.57, n.1, p.104-111, 2005.

AROUCA, C.L.C.; FONTES, D.O.; BAIÃO, N.C. et al. Exigências de lisina para suínos machos castrados selecionados geneticamente para deposição de carne magra na carcaça, dos 95 aos $122 \mathrm{~kg}$. Revista Ciência e Agrotecnologia, v.31, n.2, p.531-5939, 2007.

ASSOCIAÇÃO BRASILEIRA DOS CRIADORES DE SUÍNOS (Estrela, RS). Método brasileiro de classificação de carcaças. Estrela, 1973. 17p.

ALMEIDA, E.C.; RODRIGUES, V.V.; AMARAL, N.O. et al. Desempenho de suínos em terminação recebendo rações formuladas com diferentes níveis de lisina, suplementadas ou não com ractopamina. In: PORKEXPO \& FÓRUM INTERNACIONAL DE SUINOCULTURA, 4., 2008, Curitiba. Anais... Curitiba, 2008, p.121.

BRIDI, A.M.; SILVA, C.A. Métodos de avaliação de carcaça e da carne suína. Londrina: Midiograf, 2007. 97p.

BOGGS, D.L.; MERKEL, A.R. Live animal carcass evaluation and selection manual. Dubuque: Kendal/Hunt, 1979. 256p.

CLINE, T.R.; CROMWELL, G.L.; CRENSHAW, T.D. et al. Further assessment of the dietary lysine requirement of finishing gilts. Journal of Animal Science, v.78, n.4, p.987-992, 2000.

D'MELLO, J.P.F. Amino acid supplementation of cereal-based diets for non-ruminants. Animal Feed Science and Technology, v.45, n.1, p.1-18, 1993.

FRIESEN, K.G.; NELSSEN, J.L.; GOODBAND, R.D. et al. The effect of dietary lysine on growth, carcass composition, and lipid metabolism in high-lean growth gilts fed from 72 to 136 kilograms. Journal Animal Science, v.73, p.3392-3401, 1995. GONÇALVES, T.M.; BERTECHINI, A.G.; DE KONING, G. et al. Lisina, energia, sexo e períodos experimentais em características de carcaça de suínos híbridos. In: CONGRESSO BRASILEIRO DE VETERINÁRIOS ESPECIALISTAS EM SUÍNOS, 1999, Belo Horizonte. Anais... Belo Horizonte: ABRAVES, 1999. p.453. 
KIEFER, C.; SANCHES, J.F. Metanálise dos níveis de ractopamina em dietas para suínos em terminação. Revista Brasileira de Zootecnia, v.38, n.6, p.1037-1044, 2009.

KILL, J.L.; DONZELE, J.L.; FERREIRA, A.S. et al. Efeito de planos de nutrição sobre as características de carcaça e rendimento de carne de leitoas com elevado potencial genético, abatidas aos $105 \mathrm{~kg}$. In: REUNIÃO ANUAL DA SOCIEDADE BRASILEIRA DE ZOOTECNIA, 39., 2002, Recife. Anais... Recife: Sociedade Brasileira de Zootecnia, 2002a. (CD-ROM).

KILL, J.L.; DONZELE, J.L.; SILVA, M.V.G.B. et al. Efeito de planos de nutrição sobre as características de carcaça de leitoas com elevado potencial genético, abatidas aos $115 \mathrm{~kg}$. In: REUNIÃO ANUAL DA SOCIEDADE BRASILEIRA DE ZOOTECNIA, 39., 2002, Recife. Anais... Recife: Sociedade Brasileira de Zootecnia, 2002b. (CD-ROM).

KNABE, D.A. Optimizing the protein nutrition of growingfinishing pigs. Livestock Production Science, v.60, p.331-341, 1996.

MARINHO, P.C.; FONTES,D.O.; SILVA, F.C.O. et al. Efeito da ractopamina e de métodos de formulação de dietas sobre o desempenho e as características de carcaça de suínos machos castrados em terminação. Revista Brasileira Zootecnia, v.36, n.4, p.1061-1068, 2007a.

MARINHO, P.C.; FONTES, D.O.; SILVA, F.C.O. et al. Efeito dos níveis de lisina digestível e as características de carcaça de suínos machos castrados em terminação. Revista Brasileira Zootecnia, v.36, n.6, p.1791-1798, 2007b.

MERSMANN, H.J. Overview of the effects of beta-adrenergic receptor agonists on animal growth including mechanisms of action. Journal of Animal Science, v.76, p.160-172, 1998.

MITCHELL, A.D.; SOLOMON, M.B.; STEELE, N.C. Influence of level of dietary protein or energy on effects of ractopamine in finishing swine. Journal of Animal Science, v.69, p.4487-4495, 1991.

MOREIRA, I.; GASPAROTTO, L.F.; FURLAN, A.C. et al. Exigência de lisina para machos castrados de dois grupos genéticos de suínos na fase de terminação, com base no conceito de proteína ideal. Revista Brasileira de Zootecnia., v.31, p.96-103, 2002.

OLIVEIRA, A.L.S.; DONZELE, J.L.; OLIVEIRA, R.F.M. et al. Lisina para suínos machos castrados de alto potencial genético para deposição de carne magra dos 110 aos $125 \mathrm{~kg}$. I. Efeito sobre o desempenho. In: REUNIÃO ANUAL DA SOCIEDADE BRASILEIRA DE ZOOTECNIA, 39., 2002, Recife. Anais.. Recife: Sociedade Brasileira de Zootecnia, 2002. (CD-ROM).

OLIVEIRA, A.L.S.; DONZELE, J.L.; OLIVEIRA, R.F.M. et al. Lisina para suínos machos castrados selecionados para deposição de carne magra na carcaça dos 95 aos $110 \mathrm{~kg}$. Revista Brasileira de Zootecnia, v.32, n.2, p.337-343, 2003.

PEREIRA, B.D.; MAIA, J.C.S.; CAMILOT, R. Eficiência técnica na suinocultura: efeito dos gastos com o meio ambiente e da renúncia fiscal. Revista Brasileira de Engenharia Agrícola e Ambiental, v.12, n.2, p.200-204, 2008.

ROSTAGNO, H.S.; ALBINO, L.F.T.; DONZELE, J.L. et al. Tabelas brasileiras para aves e suínos: composição de alimentos e exigências nutricionais. 2.ed. Viçosa, MG, 2005. 186p.

SANCHES, J.F.; KIEFER, C.; MOURA, M.S. et al. Niveis de ractopamina para suinos machos castrados em terminação e mantidos sob conforto térmico. Ciência Rural, v.40, n.2, p.403-408, 2010.

SPURLOCK, M.E.; CUSUMANO, J.C.; MILLS, S.E. The affinity of ractopamine, clenbuterol, and L-644,969 for the betaadrenergic receptor population in porcine adipose tissue and skeletal muscle membrane. Journal of Animal Science, v.71, p.2061, 1993

STAHLY, T.S.; WILLIAMS, N.H.; SWENSON, S. Impact of genotype and dietary amino acid regimen on growth of pigs from 6 to $25 \mathrm{~kg}$. Journal of Animal Science, v.72, p.165, 1994.

UNIVERSIDADE FEDERAL DE VIÇOSA - UFV. Manual de utilização do programa SAEG (Sistema para análises estatísticas 8.0). Viçosa, MG: Universidade Federal de Viçosa, 1999. 141p.

XIAO, R.; XU, Z.; CHEN, H. Effects of ractopamine at different protein levels on growth performance and carcass characteristics in finishing pigs. Animal Feed Science and Technology, v.79, n.119-127, 1999 